\title{
Determinants of Customer Loyalty for Moslem Fashion: A Study The Largest Moslem Population (Indonesia)
}

\author{
Afifah Nur Millatina', Naily Rohmah², and Irham Zaki ${ }^{1}$ \\ ${ }^{1}$ Department of Islamic Economic Science, Postgraduate School Airlangga University, Surabaya, \\ Indonesia \\ ${ }^{2}$ Department of Islamic Business Management, Tazkia University Collage of Islamic Economics, \\ Bogor, Indonesia
}

\section{Abstract}

The development of the fashion world experienced a significant increase in the last few decades. Indonesia has a huge opportunity in the Muslim fashion sector when compared to other countries, because the majority of the population is Muslim. The Indonesian government realizes that even Indonesia is proclaimed to be a benchmark for world Muslim fashion in 2020. This is very possible considering the Muslim fashion

Corresponding Author: Afifah Nur Millatina milea1903@gmail.com

Received: 10 February 2019 Accepted: 14 March 2019 Published: 28 March 2019

Publishing services provided by Knowledge E

(c) Afifah Nur Millatina et al. This article is distributed under the terms of the Creative Commons Attribution License, which permits unrestricted use and redistribution provided that the original author and source are credited.

Selection and Peer-review under the responsibility of the ICIEBP Conference Committee. industry in Indonesia has experienced growth since the 1990s based on data from the Organization of the Islamic Conference (OIC). One of the biggest brands in Indonesia is HijUp. This aims to analyze the effect of brand images and online promotion strategy on customer satisfaction and loyalty. The analysis technique used is quantitative approach. The sample in this study were 100 HijUp respondents, using the Maximum Likehood (ML) estimation method. This research uses Structural Equation Modeling (SEM) method with LISREL 8.72 measuring instrument. The results of this study indicate the positive influence of brand image on customer satisfaction and customer loyalty. Furthermore, there is a positive influence of online promotion strategies on customer satisfaction, but there is a negative influence on customer loyalty. Furthermore, there is a positive influence between customer satisfaction and customer loyalty.

Keywords: Brand Image, Online Promotion Strategy, Customer Satisfaction, Customer Loyalty, Fashion Muslim

\section{Introduction}

The development of halal industry in the world continues to increase. This is driven by the increasing awareness of Muslims in affirming their need for halal-based products and services. Not only Muslims but non-Muslims also began to be interested in the halal industry, in this study especially in the field of Muslim fashion. This is consistent with previous studies that modest fashion can also appeal to non-Muslim consumers (Thomson Reuters, 2015). There is indeed a growing number of religious communities 
that are also growing in other communities (Lewis and Tarlo 2011). This is evidenced in the data volume of millennial generation interactions in countries and sectors.

\begin{tabular}{|c|c|c|c|c|c|c|c|}
\hline & $\begin{array}{l}\text { Islamic } \\
\text { Finance }\end{array}$ & Halal Food & $\begin{array}{l}\text { Modest } \\
\text { Fashion }\end{array}$ & Halal Travel & $\begin{array}{c}\text { Halal } \\
\text { Media and } \\
\text { Recreation }\end{array}$ & $\begin{array}{l}\text { Halal } \\
\text { Pharmaceuticals } \\
\text { and Cosmetics }\end{array}$ & Total \\
\hline Indonesia & 37,500 & 4,200 & 68,500 & 4,600 & 4,200 & 7,800 & 126,800 \\
\hline Malaysia & 60,600 & 7,400 & 5,300 & 1,900 & 1,400 & 8,100 & 84,700 \\
\hline Pakistan & 4,000 & 1,200 & 1,500 & 500 & 48,500 & 200 & 55,900 \\
\hline USA & 2,500 & 6,800 & 1,100 & 1,500 & 2,200 & 500 & 14,600 \\
\hline Philippines & 400 & 7,700 & 1,200 & 100 & 200 & 4,300 & 13,900 \\
\hline India & 1,800 & 2,500 & 500 & 300 & 5,200 & - & 10,300 \\
\hline Saudi Arabia & 900 & 600 & 900 & 100 & 5,300 & - & 7,800 \\
\hline UK & 600 & 2,700 & 400 & 300 & 1,000 & 100 & 5,100 \\
\hline Turkey & - & - & - & - & 4,900 & - & 4,900 \\
\hline UAE & 300 & 300 & 200 & - & 3,000 & - & 3,800 \\
\hline
\end{tabular}

Figure 1: Volume of Millennial Generation Interactions in Countries and Sectors (Global Islamic Economy Report 2016/2017).

The picture above shows that Indonesia is not only the highest number in the field of modest fashion but there is a very significant increase with a value of 68,500 compared to the country of Malaysia which is only 5,300 and the country of Pakistan is only 1,500 interactions. This shows the high demand for modest fashion in the country of Indonesia with a majority Muslim population. Indonesia is among the top ten countries with the highest Global Islamic Economy Indicator with Malaysia, Bahrain, Saudi Arabia, Oman, Pakistan, Kuwait, Qatar and Jordan. With this Indonesia can have enormous opportunities for entrepreneurs and halal industries to create a product, especially in the fashion sector (Global Islamic Economy Report 2016/2017).

The growth of the Muslim fashion industry in Indonesia is currently attracting international attention. Indonesia currently occupies a country with a large level of Muslim fashion exports to Muslim countries such as Malaysia, Turkey, Brunei Darussalam, the United Arab Emirates, and other Islamic countries in the Middle East. According to data submitted by the Acting Director General of National Export Development of the Ministry of Trade, Tjahya Widayanti in her press release in 2016 stated that an increase in exports was 2.13\% compared to January 2015 from USD 366.2 million to USD 374 million. Muslim clothing export products each year increase rapidly. Which is by referring to Thomson Reuters data in the State of the Global Islamic Economy 2015.

The development of the fashion world has experienced a significant increase more than two decades. From the data that has been attached earlier, Indonesia is determined 
to be a benchmark for the world's Muslim fashion by 2020 (Minister of Tourism and Creative Economy, 2014). The determination and aspiration will not be difficult for Indonesia. Because the composition of Indonesia's majority Muslim population will be very helpful to make it happen. According to data from the Ministry of Religion in the 2013 census, the population that embraces Islam in Indonesia is very large. There are about $87.21 \%$ or around $207,176,162$ people who are Muslims from a total of $237,641,326$ inhabitants of Indonesia. This shows that there is tremendous potential for Muslim fashion in the largest moslem population

According to Rudy Ramawy, Google Indonesia's Head of Country about online shopper, the best-selling products for sale online in Indonesia are fashion products. The data taken based on a survey conducted by Google in January 2014 of approximately 1,300 Indonesians, shows that fashion is the most popular product category for online consumers in Indonesia as many as $78 \%$ of respondents buy fashion products online (IndoTelko.com). Supported by the 2017 infographic survey data by the Indonesian Internet Service Providers Association (APJII) measures the growth of internet users from year to year with a total of 110.2 million in 2015, then with a total of 132.7 million in 2016 and In 2017 the number of Indonesian internet users penetrated a number of $54.68 \%$ of the population or 143.26 million of the total Indonesian population of 262 million.

Currently the prospect of the Indonesian Muslim fashion industry can also be seen with many emerging Muslim fashion products brands. According to W \& S Indonesia's data, Digital Marketing in Indonesia, which conducts periodic surveys of Muslim fashion brands, mentions that in the period of September 2015 and the May and September periods in 2016, there were five different popular brand indexes and intense competition among each each brand. Brand HijUp is one of the Indonesian product brands that have always entered the popular brand index in 2015 and 2016. The strategy that HijUp is doing is always updated on fashion because according to the survey, customers will experience boredom within 3 months. According to Diajeng, the CEO of HijUp is the key to the success of online stores currently located in brands and online stores and focusing on the brand. The focus in this case means that the brand has its own uniqueness that makes customers not choose another brand.

Against the background of the above information, research related to promotion online strategy and brand image for muslim fashion in Indonesia is relatively necessary. In this case, the author focuses the discussion customer understanding about brand HijUp one of famous brand in the largest moslem population. The results of this study are 
expected to provide valid, empirical and academic data for the benefit of the Indonesian ministry in making policies.

\section{Literature Review}

According to Puspitasari (2006), brands are names, terms, symbols, or special designs or some combination of these elements designed to identify the goods or services offered by the seller. Indicators that influence online promotion strategies include (Lai, 2013): accurate, no buffering, clarification and details, clarity of product ingredients, and accuracy of product prices.

According to Olorunniwo (2006) there are four main dimensions of customer satisfaction which are arranged in order of relative importance, the dimensions that affect customer satisfaction are satisfied, choice, think, feel.

whereas according to Grifin (2005), customer loyalty is more associated with behavior than with attitude. Griffin's definition is also supported by Petter's definition (2005) which states that consumer loyalty is the behavior of consumers who like a brand or product, where consumers have a commitment to repeat purchases continuously and use it and override other competing products.

The discovery of Wen (2012) which focuses on the influence of brand image has concluded that there is a positive relationship between the online brand image of the trust product brand, with the implications of managerial strategies to get more customer loyalty in the Taiwan market. In line with the research, the image of a brand greatly influences consumer confidence, and has a profound effect on the influence of brand expansion attitudes (Gulzar, 2011).

In contrast to the findings produced by Mogire (2014) who tested two products in one brand. Concluding that there is a strong positive relationship between advertising strategy and brand equity of one of its products, but the other products in the brand ad strategy has no effect.

Online promotion is a process of activities carried out by parties (companies) in offering products or services advertised through online media (internet), so there is no direct face to face between buyers and sellers. Khan's writing results (2012) revealed that there was a positive influence between online promotion on consumer satisfaction.

Promotional activities are used to stimulate consumers and sellers to buy products. Can also be used as a means of communication between producers and consumers to introduce products, both types of colors, shapes, prices and the quality of products offered or produced by the company. Grover (1992) explains that promotion has a 
positive effect on consumer loyalty, but Huang (2011) explains otherwise that transactionoriented promotion (short-term) has no effect on consumer loyalty.

\section{Methods}

This study uses a quantitative approach. Based on data and information collection techniques, in this study using one type of data, namely primary data. Collection data was carried out through surveys using questionnaires to respondents. The population of this research data is all customers who have purchased products on the HijUp brand. The sample used by 100 respondents is in accordance with the study according to Ghazali (2008) using Maximum Likehood (ML) minimum required sample of 100 and maximum 200 .

The data is then processed using the statistical method of Structural Equation Modeling (SEM) operated through LISREL Sarjono \& Julianita (2015).

\section{Discussion}

TABLE 1: Respondents' Profile.

\begin{tabular}{|c|c|c|}
\hline \multicolumn{2}{|c|}{ Note } & \multirow{2}{*}{$\begin{array}{c}\text { Presentation } \\
98 \%\end{array}$} \\
\hline Gender & Female & \\
\hline Age & $18-29$ & $65 \%$ \\
\hline Level of Education & S1 & $48 \%$ \\
\hline Employment Level & $\begin{array}{c}\text { College } \\
\text { Student/Student }\end{array}$ & $35 \%$ \\
\hline Income Level & $>\operatorname{Rp} 5.500 .000$ & $38 \%$ \\
\hline
\end{tabular}

The table above shows that the majority female respondents, aged $18-29$ years, level of education from S1, then employment level is college student / student and the last from the income level is $>$ Rp.5,500,000. From the above results, it can be used for HijUp to develop promotional strategies in determining potential customer segments.

Based on table 2, it can be seen that the results show that most GOF size shows a good match so it can be concluded that the GOF measurement model is good.

Based on the processed data from the brand variable t-value to satisfaction is 2.48. Then the promotion variable t-value is satisfied with the number 2.98. Then the t-value variable satisfaction with loyalty shows 4.56 . Then the t-value of the brand variable on loyalty shows 2.18 . This shows that the t-value>t-table (1.96), meaning that the 
TABLE 2: Estimasi Results Goodness of Fit.

\begin{tabular}{l|c|c|c|}
\hline GoF size & $\begin{array}{c}\text { Match Level } \\
\text { Target }\end{array}$ & $\begin{array}{c}\text { Estimation } \\
\text { Results }\end{array}$ & Match Level \\
\hline X2 (Chi-square) & $\mathrm{P} \geq 0,50$ & 183.421 & Good fit \\
\hline RMSEA & RMSEA $\leq 0,08$ & 0,086 & Marginal fit \\
\hline GFI & GFI $>0,80$ & 0,812 & Perfect fit \\
\hline AGFI & AGFI $\geq 0,90$ & 0,739 & Marginal fit \\
\hline TLI & (NNFI) TLI $>0,90$ & 0,962 & Good fit \\
\hline CFI & CFI $>0,90$ & 0,969 & Good fit \\
\hline NFI & NFI $>0,90$ & 0,937 & Good fit \\
\hline IFI & IFI $>0,90$ & 0,969 & Good fit \\
\hline RFI & RFI $>0,90$ & 0,923 & Good fit \\
\hline
\end{tabular}

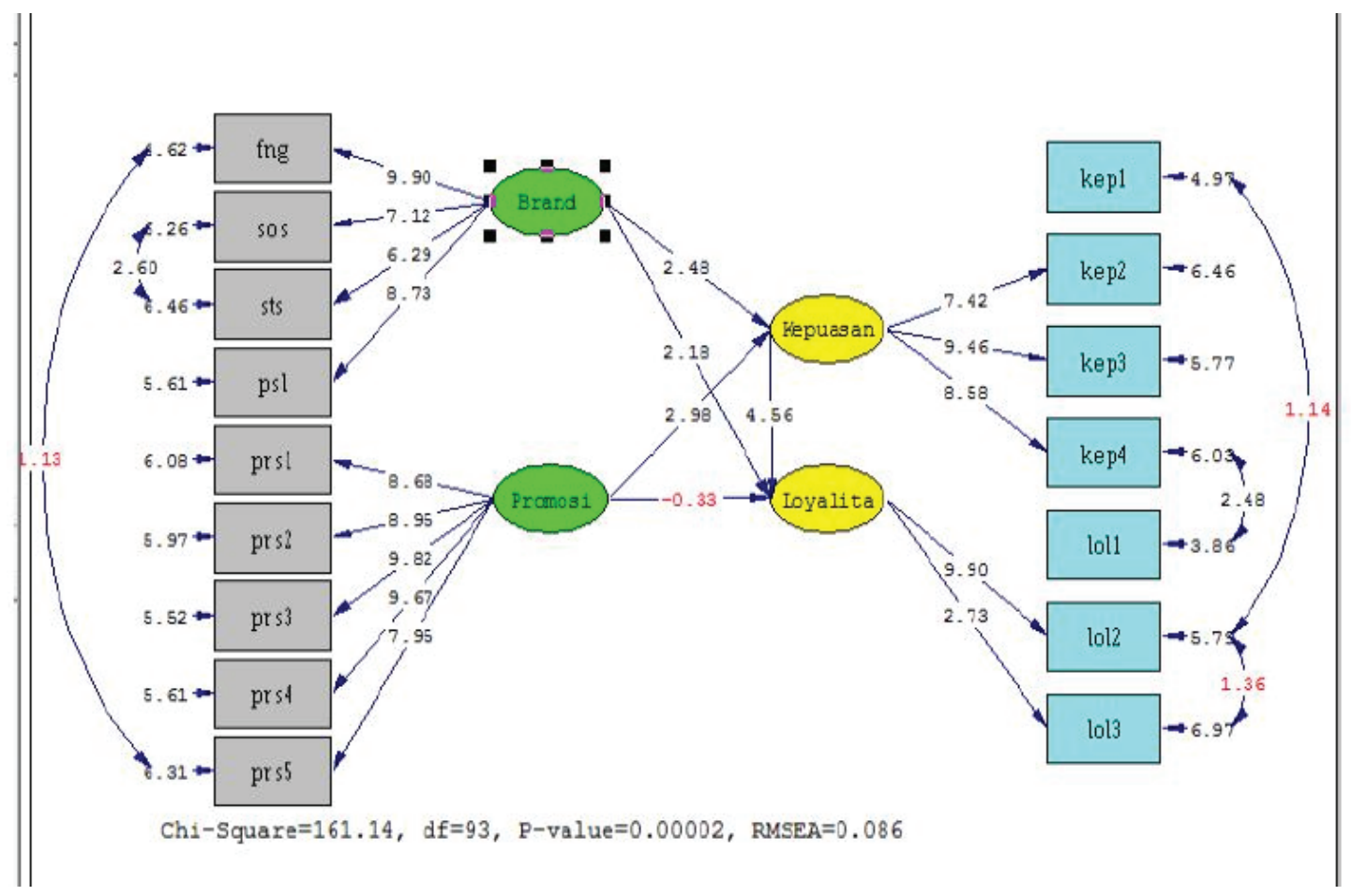

Figure 2: Model SEM T-Values Information: Brand: Brand Image; Promosi: Promotion Online Strategy; Kepuasan: Satisfaction Customer; Loyalita: Loyalty Customer.

brand, promotion of satisfaction has a positive influence and brand on loyalty has a positive effect. Then satisfaction with loyalty has a positive effect. While the t-value in the promotion variable on loyalty is -0.33 or the t-value is between -1.96 and 1.96 . This means that promotion has a negative effect on the loyalty of HijUp respondents.

Based on the results of table 3 , it can be explained that $\mathrm{H} 1$ and $\mathrm{H} 3$ are explained by $\mathrm{H} 1$ accepted and $\mathrm{HO}$ is rejected, this is supported by the theory of Suharyono (2015) which states that the influence of brand image and product quality on customer satisfaction and 
TABLE 3: Hypothesis Analysis.

\begin{tabular}{l|l} 
Hypothisis & Statement \\
$\mathrm{H} 1$ & $\begin{array}{l}\text { Brand image influence on customer } \\
\text { satisfaction }\end{array}$ \\
$\mathrm{H} 2$ & $\begin{array}{l}\text { Promotion online strategy influence } \\
\text { on customer satisfaction }\end{array}$ \\
$\mathrm{H} 3$ & $\begin{array}{l}\text { Brand image influence on loyality } \\
\text { customer }\end{array}$ \\
$\mathrm{H} 4$ & $\begin{array}{l}\text { Promotion online significant strategy } \\
\text { influence on loyalty customer }\end{array}$ \\
$\mathrm{H} 5$ & $\begin{array}{l}\text { Satisfaction customer significant } \\
\text { influence on loyalty customer }\end{array}$
\end{tabular}

\begin{tabular}{|c|}
\hline T-value \\
\hline 2,48 \\
\hline 2,98 \\
\hline 2,18 \\
\hline$-0,33$ \\
\hline 4,66
\end{tabular}

\begin{tabular}{|l|}
\hline Result \\
\hline Positive-significant \\
\hline Positive-significant \\
\hline Positive-significant \\
\hline Negative-significant \\
\hline Positive-significant
\end{tabular}

loyalty results in accordance with the theory of Betty's research (1999) In this writing the indicator that has the highest value is the function (fng) where the function explains that consumers are satisfied with good product quality, so that consumers have confidence in the HijUp product offered.

Furthermore for $\mathrm{H} 2$ explained that $\mathrm{H} 1$ is accepted and for $\mathrm{HO}$ is rejected, this is in accordance with the research conducted by Khan (2012) explaining the influence of image and promotion on customer satisfaction and its impact on customer loyalty. The writing of this indicator that has a high value is clarification and details (prs3), where the indicator explains that consumers are satisfied with detailed product information, and provide detailed information so that consumers are satisfied with the HijUp product offered.

For $\mathrm{H} 4$, it is explained that $\mathrm{H} 1$ is rejected and $\mathrm{HO}$ is accepted, in this research promotion has no effect on customer loyalty, because the online promotion strategy carried out by HijUp is only transaction oriented (short term). This is supported by Huang's (2011) research which states that promotion has two types, namely transaction orientation which has short-term effects (only once) and relationship orientation that puts customer benefits first and promotes the maintenance of long-term relationships. Online promotion strategies will create loyalty customers when there is a mediating variable of customer satisfaction first. It can be concluded that creating customer loyalty can not only be influenced by online promotion strategy variables but can be influenced by service quality variables or from price variables.

The last for $\mathrm{H} 5$, it is explained that $\mathrm{H} 1$ is accepted and for $\mathrm{HO}$ is rejected, this result is supported by research conducted by Cheng \& Yuang (2008) that concludes that there is a positive influence between customer satisfaction and customer loyalty. Writing this highest indicator of satisfaction is a value of 10.14 , this proves that HijUp consumers 
are satisfied with the product that HijUp offers, thus creating a loyalty. then the highest indicator of the variable customer loyalty is (Iol1) word of mouth that when consumers are satisfied with HijUp products, consumers will say good things about HijUp services to others so that consumers recommend HijUp products to friends or other people while inviting others to buy HijUp product and become part of HijUp.

\section{Conclusions}

From the results of this study to determine the loyalty customers of Muslim fashion products in the largest moslem population country is not only from the brand image variable, online promotion strategy and satisfication of the customer, but there are other variables that can affect customer loyalty, among others, from product service quality variables. or services and from product prices. So it can be concluded that there is a positive influence between brand image on customer satisfaction and customer loyalty. Furthermore, the results of the variable online promotion strategies on customer satisfaction have a positive influence, but customer loyalty has a negative influence. Furthermore, the last for variable customer satisfaction has a positive influence on customer loyalty.

\section{Recommendations}

Referring to the conclusions of the results of this study, the authors convey a number of suggestions to the parties related to this research, including the following:

1. Maintain a brand image and promotion online strategy now while continue to develop, innovate both in terms of products, fashion design and promotion media online

2. Examine the variables that have a positive influence in this research through the HijUp research and development ( $\&$ D) team to be maintained quality and more improved by utilizing business developments, markets and of course in accordance with the characteristics of the HijUp vision and mission.

3. Maintain cooperation with famous villages already has a brand and quality to market product designers in HijUp. So that HijUp will be a satisfying choice in the eyes consumers and make to loyal consumers. 
4. It could also be with watering creative teams and experts internet marketing on all social media and the web to always maintain the quality of promotions online and websites develop and social mediaHijUp.

\section{References}

[1] Betty, R. a. (1999). Customer Benefits And Company Of Consequences CustomerSalesperson Relationships In Retailing. Journal of name retailting.

[2] Cheng, T.C.E., L. C. F., Yeung, A. C. L. 2008. "The Driving Forces of Customer Loyalty: A Study of Internet Service Providers in Hong Kong". Internasional Journal of E-Business Research. Vol. 4. No. 4, pp. 26-42.

[3] Dengan Program LISREL 8.8 Edisi II. Semarang: Badan Penerbit Universitas Diponegoro.

[4] Ghozali, Imam. 2008. Struktural Equation Modelling: Teori, Konsep dan Aplikasi

[5] Grifin, J. (2005). Customer Loyality In Menumbuhkan dan Mempertahankan Kesetiaan Pelanggan. Jakarta.

[6] Grover. (1992). evaluating the multiple effect of retai Ipromotion on brand loyality and brand switching segment.

[7] Gulzar, A. (2011). impact of brand image, trust and affect on customer brand extension attitude: the mediating role of brand loyality. Journal management sciences.

[8] http://www.iedcdubai.ae/assets/uploads/files/ar_20142015_1448266389.pdf.

[9] Huang, W. P. (2011). Effects Of Promotion On Relationship quality and customer loyality in the airline industry. jounal of management.

[10] Khan et., a. (2012). Determinants of Customer Satisfaction in Fast Food Industry. International Journal of Management Strategy.

[11] Kotler. (2008). Strategic Brand and Management In M. a Equity, Third Edition. New Jersey: Pearson Education.

[12] Lai, W. H. (2013). online promotion and its influence on destination awareness and loyalty in the tourism industry. journal management and applied economics.

[13] Lewis, Reina and Emma Tarlo. 2011. Modest Dressing. Faith-based Fashion and Internet Retail.

[14] Mogire. V. B. (2014). Adversting Promotion Strategy and Brand Equity: a Comparative Study of Ariel and Omo Washing Powders. Nairobi - Kenya.

[15] Olorunniwo. (2006). a typology analysis of sevis quality, customer satisfaction and behavioral intenttion. 
[16] Olorunniwo. (2006). A Typology Analysis of Sevis Quality, Customer Satisfaction, and Behavioral Intenttion.

[17] Petter, P. J. (2005). Customer Behaviour and Marketing Strategy. New York: McGraw Hill. Project Summary. London, UK: University of the Arts London, London College of Fashion.

[18] Puspitasari, A. (2006). Hubungan Antara Brand Equity dan Minat Konsumen: Peubahan Nama/Merek Panasonic dari Merek National. Jurnal Riset Manajemen dan Bisnis. Sarjono, Haryadi. \& Julianita, Winda. 2015. Structural Equation Modeling (SEM). Jakarta: Salemba Empat.

[19] Suharyono. (2015). pengaruh citra merek terhadap kepuasan pelanggan dan loyalitas pelanggan(survei pada konsumen produk busana muslim dian pelangi di malasyia).

[20] Thomson Reuters. 2015. State of the Global Islamic Economy 2014-2015 Report.

[21] Wen, Y. s. (2012). The Influence of Online Brand Image and Perceived Risks on Online Customer Loyalty for Women's Apparel in Taiwan Market. 